\title{
ACUTE URINARY TRACT OBSTRUCTION
}

\author{
Djordje Aleksic
}

Department of Urology, Clinical Center Zvezdara, Belgrade, Serbia

\section{AKUTNE OPSTRUKCIJE UROTRAKTA \\ Đorđe Aleksić}

Kliničko odljenje za urologiju, Klinički centar Zvezdara, Beograd, Srbija

\section{ABSTRACT}

The kidneys are paired organs with the primary function of helping to remove toxins from the body and regulate water balance. They are vital to survival. After urine is produced in the kidneys, it must pass into the bladder, where it can be stored before being eliminated from the body through the urethra. Urinary tract obstruction is a common problem encountered by urologists, primary care physicians, and emergency medicine physicians. Urine can become obstructed at any point in this pathway. There are three groups of urinary tract obstructions: 1) obstruction of the urinary tract lumen; 2) obstruction of the urinary tract wall; and 3) extrinsic obstruction, which can press on the urinary tract lumen. An obstruction can be present from birth or develop later in life. The most common causes of obstruction include stones, strictures, tumours, and bladder dysfunction. These obstructions may result in the hydronephrosis of one or both kidneys, which, if left untreated, may lead to the deterioration of renal function. The goal of an initial treatment of urinary tract obstruction is to remove the obstruction. Later, we treat the cause that led to the obstruction. The bottom line is that all efforts should be made to preserve kidney function to avoid the need for dialysis or renal transplantation.

Keywords: urinary tract obstruction, obstructive uropathy, urethral catheter, suprapubic catheter, ureteral stent.

\section{SAŽETAK}

Bubrezi su parni organi, neophodni za život jer pomažu u eliminaciji toksičnih materija iz organizma $i$ učestvuju u regulaciji vodno elektrolitnog balansa. Urin koji se stvara u bubrezima transportuje se ureterima do mokraćne bešike u kojoj se privremeno zadržava do akta mokrenja. Opstrukcije urotrakta su čest problem sa kojim se sreću urolozi, lekari opšte prakse kao i oni koji rade u urgentnoj službi. Prepreka može postojati na bilo kom delu urinarnog trakta. Obstrukcije urinarnog trakta se mogu podeliti u 3 grupe 1) obstrukcije unutar samog lumena 2) obstrukcije na zidu urinarnog trakta 3) obstrukcije nastale zbog spoljašnje kompresije urotrakta. Najčešći uzroci obstrukcija su: kalkulusi, suženja, tumori I disfunkcije mokraćne bešike. Obstrukcije dovode do formiranja hidronefroze na jednom ili oba bubrega i ukoliko se ne leče izazivaju oštećenje renalne funkcije. Cilj lečenja obstrukcije urotrakta u hitnoj ambulantnoj službi je dezopstrukcija. Kasnije se pristupa lečenju osnovne bolesti koja je dovela do obstrukcije. Sve napore treba usmeriti ka očuvanju bubrežne funkcije kako bi se izbegla eventualna dijaliza i transplantacija.

Ključne reči: obstrukcija urinarnog trakta, obstruktivna uropatija, uretralni kateter, suprapubični kateter, ureteralni stent. 
Acute urinary tract obstructions are urgent conditions in urology. It is essential to recognize them quickly. This is a significant task for all medical doctors, including general practitioners or those engaged in a highly specialized medical branch (1). When patients with an obstruction reach a urologist, it can often be too late to adequately help them. Obstruction removal does not mean that a complete recovery of urinary tract function will be accomplished. Functional urinary tract recovery largely depends on the obstruction duration. Thus, a timely discovery is essential for a good final outcome, which especially emphasizes the significance of diagnosis and increases the responsibility of all medical doctors. Some of these conditions can be easily resolved in any general surgical practice. More complicated patients, as well as ones with differential diagnostic uncertainties, should be referred to a urologist.

The purpose of the urinary tract is to conduct urine from the kidneys to the urinary bladder, where it is temporarily stored and then excreted from the body. An obstacle can occur anywhere, from the renal calyces to the external urinary meatus (2).

Urinary tract obstructions can be divided into three major groups: obstructions in the urinary tract lumen, obstructions arising due to changes on the urinary tract wall and extrinsic obstructions that compress the urinary tract (3). The most frequent causes are listed in Table 1.

The urinary tract lumen is most frequently obstructed by a stone. Calculus disease can occur in all age groups. However, it is most common in middle age, and men are three times more affected. An obstruction should be con- sidered in all patients with neurological disorders (diseases and injuries). Obstructions in elderly men are mostly caused by benign prostatic hyperplasia (BPH). Obstruction in women most commonly occur due to genitourinary prolapse, pregnancy, malignant diseases of the gynaecological region, and radiation for a malignancy. Obstructions should considered after all small pelvis surgeries, especially gynaecological ones (4).

Urethral obstruction caused by the prostate is due to changes in the urinary bladder wall. First, the fibres of the detrusor hypertrophy to make stronger contractions to overcome the pressure of the prostate on the initial part of the urethra. Hypertrophic trabeculae as well as cells and diverticula can be observed. The contractile capacity of the urinary bladder detrusor gradually decreases, leading to an increasing amount of residual urine (5).

Consequently, the intraluminal pressure in the bladder increases and transfers to the ureters and kidneys, leading to damage. The damage is caused by the direct compression of the dilated pyelocaliceal system on the renal parenchyma, as well as the compression on the arcuate arteries, which leads to the ischemic changes.

A normal renal pelvic pressure is 6 to $12 \mathrm{mmHg}$. In an acute obstruction (most commonly caused by a stone), strong contractions of the ureter occur and cause a sudden rise in pressure from 50 to $70 \mathrm{mmHg}$. Because urine is still excreted, the pressure can increase to 100 $\mathrm{mmHg}$, which is 10 to 15 times higher than normal (6). The pressure leads to the distension of the wall of the ureter and renal capsule, which is rich in nerve endings. This can explain the extremely strong pain these

Table 1. Causes of urinary obstruction

\section{CAUSES OF URINARY OBSTRUCTION}

\begin{tabular}{|c|c|}
\hline Site of obstruction & Possible causes \\
\hline Within the lumen & $\begin{array}{l}\text { - Stones } \\
\text { - Blood clot } \\
\text { - Necrotic renal papillae } \\
\text { - Tumour of renal pelvis or ureter }\end{array}$ \\
\hline Within the wall & $\begin{array}{l}\text { - Pinhole meatus (urethral meatus stenosis) } \\
\text { - Congenital urethral valves } \\
\text { - Ureteric, urethral or ureterovesicular stricture } \\
\text { - Bladder neck stenosis } \\
\text { - Neurogenic bladder } \\
\text { (e.g., after a spinal trauma, multiple sclerosis, surgery in the pelvis, etc.) } \\
\text { - Congenital megaureter } \\
\text { - Ureteral endometriosis }\end{array}$ \\
\hline $\begin{array}{l}\text { Pressure from } \\
\text { outside tract }\end{array}$ & $\begin{array}{l}\text { - Phimosis } \\
\text { - Posterior urethral injuries } \\
\text { - Tumours and BPH } \\
\text { - } \text { Surgery in the pelvis } \\
\text { - } \text { Pancreatitis, appendicitis, diverticulitis } \\
\text { - Tumours of the uterus and ovaries, adnexal abscesses } \\
\text { - Pregnancy } \\
\text { - Retroperitoneal fibrosis } \\
\text { - Retrocaval ureter } \\
\text { - Chronic granulomatous disease } \\
\text { - Effects of radiation } \\
\text { - UPJ obstructed by aberrant blood vessels }\end{array}$ \\
\hline
\end{tabular}


patients feel. On a pain scale, pain due to renal colic is higher than any other pain. This pain is often much stronger than labour pain.

In the acute phase of the renal colic, there is the reduction of blood flow through the kidneys and glomerular filtration system. Thus, only a small quantity of new urine is produced. Therefore, a significant dilatation of the pyelocaliceal system in the initial phases of the renal colic cannot be observed. If the obstruction is not removed, the pressure in the pyelocaliceal system can gradually decrease due to pyelovenous, pyelolymphatic, pyelo-interstitial and pyelotubular reflux. New urine quantities fill and dilate the pyelocaliceal system and ureter, and they can significantly expand if the obstruction is long lasting.

The first anatomical renal changes occur after 7 days in the distal renal tubule. The first signs of the atrophy, which is not completely reversible, then occur. The papillae are flattened, and the distal tubule is expanded. After 14 days, the obstruction causes the same changes in the proximal tubule. After a month, these changes occur in the glomerulus. The medical literature suggests that there are cases of renal function recovery even a couple of months after a complete obstruction. However, this is rare, and we must rely on the fact that, due to the abovementioned reasons, a complete obstruction must be resolved in the first seven days.

Renal colic often occurs after the intake of the large quantity of liquids or diuretics, strenuous physical activity and alcohol abuse. All of these conditions lead to stone movement.

\section{Renal colic}

Patients complain of a sudden, strong pain in the lumbar region that often expands to the iliac fossa and inguinal region (7). In men, it often spreads to the testicles and, in women, to the labia majora. It is mostly accompanied by nausea and vomiting. If the stone is near the urinary bladder, distinct dysuric problems usually occur. After the pain, macroscopic haematuria can occur. These patients are very agitated and cannot find an antalgic position; they have a need to move. Renal colic can be accompanied by signs of urinary infection and septicaemia.

\section{Urine retention}

Patients complain of impossible spontaneous micturition or urine flow in drops. Data on unintentional urine leakage may be misleading because a patient can then have so-called urine suffusion from the urinary bladder, which is overfull. Suprapubic pain is extremely strong and can sometimes present as peritoneal irritation and acute abdomen pain. Patients with acute retention and ones with neuropathy do not necessarily have a painful syndrome. Data on previous abundant haematuria and the occurrence of blood clots in the urine indicate a tamponade of the bladder by clotted blood.
Table 2. Diagnosis of acute urinary obstruction

\section{DIAGNOSIS OF ACUTE URINARY OBSTRUCTION}

ANAMNESIS

CLINICAL REVIEW

- Inspection

- Palpation

LABORATORY ANALYSIS

- Urine sediment: Le, Er, nitrites, Le esterase crystals

- Complete blood count

- Biochemistry: urea, creatinine, $\mathrm{Na}, \mathrm{K}$, glucose

"IMAGING" METHODS

- Ultrasonography

- CT scan of the abdomen and pelvis

- IVU, retrograde and antegrade pyelography

- MRI, scintigraphy

\section{Diagnosis}

Proper anamnesis is very significant in the diagnosis of an obstruction. Attention should be paid to the time of symptom onset and the symptom intensity, frequency and propagation. Information on a high body temperature and bleeding indicates the need for urgent diagnostic procedures. Acute inflammation of the ovaries, ectopic pregnancy, appendicitis, diverticulitis and biliary colic can sometimes provide similar symptoms and must considered during a differential diagnosis.

A physical examination is necessary in patients with a suspected urinary obstruction. An overfull bladder (globus vesicalis) can be seen and palpated. In young men with suspected renal colic, the testicles must be examined because testicular inflammation and, in particular, torsion, can cause very similar initial symptoms. At the beginning of the embryonic development, the testicles and kidneys are very near one another. They later separate and assume their normal positions. Therefore, their regions of innervation are very close. Thus, at the beginning, it is not always absolutely clear which organ is the real cause of the pain. Sometimes, an obstruction can be caused by a neglected phimosis or penile oedema in cardiac decompensation patients.

A laboratory diagnosis involves an analysis of urine sediment, a complete blood count $(\mathrm{CBC})$ and a basic biochemical analysis (urea, creatinine, $\mathrm{Na}, \mathrm{K}$, glycaemia). An increased number of leukocytes in the urine, positive leukocyte esterase and the presence of nitrites imply a urinary infection. If, in addition to that, the number of leukocytes is also increased in the blood and granulocytedominated, the urinary infection most likely affected the organs of the upper urinary tract (ureters and kidneys). An increased number of erythrocytes in the urine occurs in renal colic, bleeding of the tumours of urinary tract organs and urinary infections. Anaemia indicates a longlasting micro- or abundant macro-haematuria. Increased 
Table 3. Indications for emergency relief of obstruction

INDICATIONS FOR EMERGENCY RELIEF OF
OBSTRUCTION
- Complete urinary tract obstruction
- Any type of obstruction in a solitary kidney
- Obstruction with fever and/or infection
- Renal failure
- Any suspicion of neurological dysfunction*
- Nausea and vomiting sufficient to cause dehydration*
*associated with urinary tract obstruction

levels of urea and creatinine occur in the early stages of the obstruction of a solitary or simultaneous obstruction of both kidneys. (1) If only one kidney is affected, the urea and creatinine do not significantly change in the early stages of the obstruction.

Ultrasound is a simple, fast and cheap orientation method by which to evaluate the condition of the urogenital tract organs.(1) It is the method of choice in diagnosing urinary obstructions in pregnant women and young children.(1) All radiologists, and most urologists and other medical doctors with an elementary knowledge of ultrasound diagnostics, can easily assess if there is urine retention in the bladder or a dilatation of the pyelocaliceal system on kidneys. This is adequate for an initial diagnosis during the urgent admission. Unlike in this country, where ultrasound is the most frequently used method, in wealthier and more technologically developed countries in the world, a scan of the abdomen and pelvis minor is used as initial diagnosis procedure. In this way, apart from the urinary tract, the condition of its surroundings can be seen. During a diagnosis of a urinary obstruction, intravenous urography and antegrade and retrograde pyelography are very useful. However, they are mostly used to further determine any uncertainties of the initial diagnosis (8). Scintigraphy and magnetic resonance are much less frequently used and are mostly used in developed countries (9).

Acute urinary obstruction may be treated with medications or surgery.

Treatment with medication can be used if there is a partial obstruction and if there are no signs of a urinary tract infection. For the prophylaxis of urinary tract infections, broad-spectrum antibiotics, such as sulfamethoxazole-trimethoprim, nitrofurantoin, cephalosporins and fluoroquinolones, can be used in their usual therapeutic doses. Prophylaxis is essential in diabetics, patients with renal insufficiency and obstructions in a solitary kidney.

The medications of choice for the treatment of renal colic are non-steroidal anti-inflammatories, including 75 $\mathrm{mg}$ of diclofenac sodium intramuscularly or a suppository of $100 \mathrm{mg}$. If necessary, administration can be repeated after 30 minutes. In addition to being analgesic, this group of medications has anti-inflammatory and anti-oedematous
Table 4. Placement of foley catheter

\section{PLACEMENT OF FOLEY CATHETER}

- Usually a simple procedure

- Respecting the measures of asepsis

- Adequate lubrication of the urethra

- Contraindicated in suspicion of the pelvic ring fracture

- Not to discharge all the urine rapidly because of the possible bleeding as a result of decompression

effects, which help in stone elimination. Indomethacin, ibuprofen (Brufen), hydromorphine hydrochloride, metamizole (Novalgetol, Baralgin), pentazocine (Fortral) and tramadol (Trodon) can also be used.

Medical expulsion therapy (MET) is the administration of alpha-adrenergic alpha blockers, which leads to the relaxation of the musculature of the distal parts of the ureter and assists in the elimination of pelvic calculi. In both men and women, the most frequently administered medication is tamsulosin (Tamsol, Flosin, Omnic), at a dosage of 0.4 mg per day (10).

Patients with the acute renal colic should reduce liquid intake during the pain phase, eliminate anticholinergics and move as much as possible.

\section{Surgical treatment}

Acute urinary retention is most frequently resolved by the placement of a Foley catheter (Table 4). This is usually a simple procedure which can be performed by any medical doctor or trained nurse and a medical technician, using aseptic techniques. Before the catheter placement, mandatory lubrication of the urethra is mandatory to prevent microtrauma and the creation of a later stenosis. If the catheter cannot be placed through the urethra, a Cystofix cystostomy is performed by a urologist. Upon the placement of the catheter or Cystofix, care should be taken not rapidly to discharge all of the urine because of the possibility of bleeding as a result of decompression.

If there is a suspicion of a pelvic ring fracture and an observation of signs of a urethrorrhagia, the placement of the catheter is contraindicated. The placement of a Cystofix should be immediately performed (11).

If the cause of the acute retention is urinary phimosis, a dorsal incision or circumcision is performed.

A tamponade of the urinary bladder by blood clots must be cystoscopically resolved using a steel pump. It is important to extract all the clots because only then will the bleeding stop. In some cases, electrocauterization of the bleeding needs to be performed. In rare cases, a complete cystectomy ("salvage" cystectomy) should be performed.

An obstruction of the upper urinary tract is resolved by ureter probing in a retrograde manner by ureteral or double-J stents or in an antegrade manner by a percutaneous nephrostomy (12). Desobstruction is a primary priority. If possible, a ureterorenoscopy should be performed 
with a possible lithotripsy, which will definitely resolve the obstruction cause.

The conditions that require urgent desobstruction are described in the Table 2.

\section{Patient monitoring}

After desobstruction, patients can enter a period of polyuria characterized by diuresis of more than $200 \mathrm{ml}$ per hour during a minimum of 2 hours. These patients can have serious electrolyte imbalances. Therefore, they must be monitored and their intravenous infusions adjusted.

Acute urinary obstruction complications are caused by mainly urinary infections: cystitis, pyelonephritis, renal abscess and urosepsis. In rare cases, extravasation of urine with the formation of a urinoma and urinary fistula can occur. Long-lasting obstructions lead to renal insufficiency.

The outcome and prognosis of an obstruction depends on the following: the cause, location, grade and duration, as well as the presence of a urinary tract infection.

If the obstruction is removed quickly, the infection can resolve in a timely manner. If there is no renal function impairment, the prognosis and the outcome are favourable.

\section{REFERENCES}

1. Kim ED, Koch YKP, Sutherland SE; Urinary tract obstruction, eMedicine, October 2008.

2. Aaron D. Berger, MD , Marshall L. Stoller, MD. Urinary Tract Obstruction. Retrieved april 9, 2012, from http://health-fts.blogspot.com/2012/04/urinary-tractobstruction.html
3. Marković V. Acute urinary tract obstruction. In: Urgent urology 1997: 51-61

4. Marković V. Retentio urinae. In : Urology. Urological surgery 1. Novinsko izdavačka ustanova Službeni liist SRJ. 1997:263-272

5. Tanagho EA. Urinary obstruction and stasis. In: Tanagho EA, McAninch JW, eds. Smith's General Urology. New York, NY: McGraw-Hill; 2000:208-220

6. Campbell SC, Walsh PC. Pathophysiology of urinary tract obstruction. In: Wein J, ed. Campbell-Walsh Urology. Vol 2. 9th ed. Saunders; 2007:1195-226

7. Renal colic - acute, Clinical Knowledge Summaries (April 2009)

8. Chen MY, Zagoria RJ, Dyer RB. Radiologic findings in acute urinary tract obstruction. J Emerg Med. May-Jun 1997;15(3):339-43.

9. Lefort C, Marouteau-Pasquier N, Pesquet AS, Pfister C, Vera P, Dacher JN. Dynamic MR urography in urinary tract obstruction: implementation and preliminary results. Abdom Imaging. Mar-Apr 2006;31(2):232-40.

10. Chapple CR; A Comparison of Varying alpha-Blockers and Other Pharmacotherapy Options for Lower Urinary Tract Symptoms. Rev Urol. 2005;7 Suppl 4:S22-30.

11. Hampel N. Posterior urethral disruption associated with pelvic fracture: the place for delayed repair. Semin Urol. Feb 1995;13(1):34-7.

12. Elsheemy MS1, Shouman AM, Shoukry AI, Elshenoufy A, Aboulel W, Daw K, Hussein AA, Morsi HA. Ureteral stents versus percutaneous nephrostomy for initial urinary drainage in children with obstructive anuria and acute renal failure due to ureteral calculi: a prospective, randomized study. BJU Int. 2014 Apr 4. doi: 10.1111/ bju.12768. [Epub ahead of print] 